\title{
CONVERGENCES AND DIVERGENCES IN UNDERSTANDING A MALAY SUFI TEXT OF THE $17^{\text {TH }}$ CENTURY
}

\author{
Mohamad Nasrin bin Mohamad Nasir*
}

\begin{abstract}
This paper investigates the seventeenth-century Acehnese Sufi text known as Haqq al-yaqīn fī 'aqīdat al-muhaqqiqīn (The Certified Faith of the Belief of the Verifiers). Written by the Malay Sufi, Shams al-Dīn Sumatra'i (d.1630), the paper shows that this text contains aspects of Persian mysticism - although it should not be merely read as a rehash of that brand of mysticism. Persian mystical texts became well-known in Southeast Asia beginning with the famous Hamzah al-Fanșūrī (d.ca.1602). Shams al-Dīn Sumatra'ī was one of Hamzah's most important students and, similar to Hamzah, was wellversed in Persian. In the Haqq al-yaqīn, Shams al-Dīn quotes from two main Persian writers, i.e. Maḥmūd Shabistarī and 'Abd al-Raḥmān al-Jāmī. In this paper, however, we will focus on his usage of Shabistarī's Gulshan-i Raz and its commentary, the Sharh Gulshan-i Raz by Muhammad Lahiji Gilani. The main question driving this paper is whether Shams al-Dīn's usage of these quotations converges with Shabistarī's own understanding of them. In other words, did Shams al-Dīn merely follow Shabistarī, thereby constituting little more than an imitator of Persian mystical writings and commentaries? Answering this question is crucial for an understanding of how early Muslim scholars viewed text and interpretation as part of their individual identities as scholars. Such findings will also be useful for demonstrating the successful dialogue between the Persian Islamic world and the Malay Islamic world via tașawwuf or 'irfān.

Keywords: Classical Malay literature, Shams al-Din Sumatra'i, Persian literature and language, Sufism, manuscript studies.
\end{abstract}

Shams al-Dīn Sumatra'ī (d.1630) was a scholar at the court of the illustrious Acehnese ruler, Sultan Iskandar Muda (d.1636). What we know of his life before he became a court scholar, however, is little more than conjecture. In the preface to his Haqq al-yaqin, however, he tells us:

And surely this lowly/poor servant who holds onto the blessings of the Lord of all worlds, Shaykh Shams al-Dīn ibn Abī 'Abd Allāh alSumatra' $\overline{1}$, Pasai his origins ${ }^{1}$ and Aceh his place of birth and dwelling and Imam Shāfi‘ $1 \bar{t}$ the imam of his school of law (madhhab). ${ }^{2}$ 
Regarding his stature at the court of the Sultan, we have at least four references to him in the Hikayat Aceh, Adat Aceh and Bustan al-Salätin. ${ }^{3}$ In the Bustan alSalattin, for example, there is an entry on him that is somewhat akin to a brief obituary, written by Nūr al-Dīn al-Rānīrī (active in Aceh between 1637 and 1644). According to the text, Shams al-Dīn passed away at the same time as an attack on Malacca by Acehnese forces. As al-Rānīrī writes: ${ }^{4}$

It was then that Shaykh Syamsuddin ibn Abdillah al-Sumatrani had passed away which is on a Monday night of the $12^{\text {th }}$ of Rajab in the year 1039AH. The shaykh was a learned scholar in all branches of knowledge and is most famous for his knowledge in tasawwuf via the few books that he had written. ${ }^{5}$

Amongst the many works penned by Shams al-Dīn, this paper will concentrate on the recently-found manuscript entitled, Haqq al-yaqin fì 'aqìdat al-muhaqqiqin (The Certified Faith in the Belief of the Verifiers). As far as the current author is aware, only two manuscript copies of this unpublished text exist, both of which can be found at the Pusat Manuskrip Melayu, Perpustakaan Negara Malaysia. They are numbered MS2581(F) and MS1556(N) respectively. ${ }^{6}$ A brief description of each of the manuscript follows.

\section{$\operatorname{MS} 2581(F)$}

This manuscript copy of Haqq al-yaqin is bound together with four other manuscripts, none of which are writings by Shams al-Dīn. The history of the text is unknown. This is the only manuscript which is complete, including both a long muqaddimah and an ending. The handwriting is clear, making this manuscript easy to read compared to MS1556(N). Nevertheless, there are watermarks in a few places within the text, which hinder the reading of a word or (occasionally) a whole sentence. At the end of the text is a colophon that reads, "Surely he [the scribe] finished writing this treatise with the help of God the Owner, the Giver on a noble Monday night, $15^{\text {th }}$ of the blessed Rabiul Akhir during the time of dhuha in the year 1125AH," which corresponds to $10^{\text {th }}$ May 1713 during mid-morning.

\section{MS1556(N)}

As with MS2581(F), there are several other manuscripts bound together under this catalogue number. In this case, however, all are labelled as writings by Shams al-Dīn. They were bought by the Pusat Manuskrip Melayu in 1993 from a Bapak Ali from Aceh. ${ }^{7}$ Ustaz Wan Shaghir, who was then in charge of collating and cataloguing the manuscripts in Pusat Manuskrip Melayu, was responsible for labelling them as writings by Shams al-Dīn; he felt that the vast majority of the manuscripts in this bundle carried some indication of having been written 
by Shams al-Dīn. Some of the texts in this bundle were later published by Ustaz Wan Shaghir in his few works on Shams al-Dīn. ${ }^{8}$ This manuscript is written in a very small handwriting, which sometimes poses difficulties in reading. In addition, there are places where the text does not make sense, probably due to poor copying techniques. For this reason, a full reading and understanding of this text would require comparison with MS2581(F).

In Haqq al-yaqīn, we find Shams al-Dīn quoting many verses from renowned Persian poets and scholars, including Maḥmūd Shabistarī, Shāh Ni'matullāh of the Ni'matullahiyya and Nūr al-dīn 'Abd al-Raḥmān al-Jāmī. ${ }^{9}$ Of these figures, Mạmmūd Shabistarī (d.ca.740/1339-40) is undoubtedly the author Shams al-Dīn quotes most often in Persian (as opposed to Arabic): of the thirteen Persian quotations in Haqq al-yakin, twelve come from Mạ̣mūd Shabistarī. ${ }^{10}$ Predominantly, these quotations are from his Gulshan-i R $\bar{a} z .{ }^{11}$

Shams al-Dīn's ability in Persian might be compared to that of his mentor, Hamzah al-Fanșūin, who is known to have quoted extensively from the Persian poets $^{12}$ and who may, according to the late A. Hasjmy, have had a Persian father. ${ }^{13}$ Shams al-Dīn himself says in the preface to the Haqq al-yaqin that:

Surely when I saw many amongst the noble people from amongst my righteous brothers who desires greatly towards following in the footsteps of the knowers, because they do not know the language of the Arabs and the Persians but instead they only know of the speech of the Sumatrans.

This statement seems to indicate his ability in Persian as well as Arabic. As to where he may have gained his proficiency in Persian, on the one hand he may have acquired it from Hamzah. It is equally possible, however, that it points to his probable travels to India. During this period, North Sumatra was well-connected to the Indian Ocean world, with traders and scholars easily travelling to India and beyond. Certainly, Teuku Iskandar believes that Shams al-Dīn may have made this journey, explaining why his Hikayat Aceh appears to have been modelled on the Shah Nameh of Ferdowsi. Furthermore, Shams al-Dīn sometimes quotes from both Shāh Ni'matullāh, whose diwan was only accessible to his followers based in India, and Muḥammad ibn Fạ̣l Allāh al-Burhānpūrī, another famous Indian scholar. Moreover, Shams al-Dīn's ancestral home, Pasai, ${ }^{14}$ was an old port where traders of Persian, Arab and Indian heritage had frequently visited in the past. ${ }^{15}$ It is also probable that Persian communities existed in Aceh at that point. Indeed, Snouck Hurgronje, the notable nineteenth and early twentiethcentury Dutch scholar on Aceh, observed that some Acehnese were of Turkish, Arab and Persian blood. ${ }^{16}$ According to a report from fourteenth-century Ibn Battutah, these relations could have begun much-much earlier. We can safely say 
that, with all these factors swirling around the milieu of Shams al-Dīn, it is not surprising that he acquired the ability to read and probably converse in Persian.

\section{The Haqq al-Yaqīn and Gulshan-I Rāz}

The Haqq al-yaqin contains eight chapters and an introduction. It is a text written with utmost care and attempts to explain: belief in the metaphysics of the verifiers (al-muhaqqiqin), especially in regards to our relation with God; the difference between our existence and God's existence; how God manifests Himself in stages; the presence of the Divine (hadhrät ilähìyyah) in all the worlds; the perfections of God; and, ultimately, how to come close to Him via certain specific methods. A truly high-level discussion of Islamic mysticism, it can be thought of as a summary of his other work - although Shams al-Dīn may not have meant it as such, as he does not make the point in his preface, where he says that the aim of the work was help those who practice and walk in the path of the verifiers.

In contrast to the Haqq al-yaqin, the Gulshan-i Rāz was written in response to questions posed by Amir Hosayn Hosayni (d.718/1318). ${ }^{17}$ Shabistarī had written the answers to these questions in the form of poetry. As Algar explains: "The questions dealt with the definition of meditation; meritorious and sinful types of thought, the meaning of the self and travel within the self; the nature of the true wayfarer on the Sufi path; the unity of being; how the knower and the known may both be identical with the divine essence; how a created being can be described as having attained union; what is the union of Necessary and contingent (mumkin) beings; what is meant by closeness to God and distance from Him; how speech may be described as the shore of the ocean of being; the relationship between partial and universal being; the sense in which the uncreated and the created can be said to be separated from each other; and the various metaphors conventionally employed in Sufi poetry."18

As mentioned, in total there are twelve quotations from Shabistarī in the Haqq al-yaqin, only two of which are not from his Gulshan-i Rāz. Out of the ten quotations from the Gulshan-i R $\bar{a} z$, four are understood in accordance with the commentary on the Gulshan-i Rāz by Shams al-Dīn Muhammad Lāhījì (d.912/1506), entitled Mafātīh al-i'jāz fi Sharh Gulshan-i Rāz. The rest of the quotations are taken by Shams al-Dīn to support his own teachings, independent of what Lāhījì might have said. In what follows, I intend to show how Shams al-Dīn used the Gulshan-i Rāz and the commentary by Lāhījì to explicate his own teachings on taṣawwuf. 


\section{The use of the Gulshan-i Rāz and Mafātīh al-l'jāz in the Haqq al-Yaqīn}

We find the first quotation from the Gulshan-i Rāz in the introduction to the Haqq al-yakin: ${ }^{19}$

Az haqq ba har yeki khati va qismist

Mua'yyad va mabda' har yek az ismist

Bad an ismand mawjudat qaim

Va az an ismand dar tasbih daim

His limit and portion are appointed to each by "the Truth"

Each arises from and returns to one Name

In that name each creature has its being

To that name it is ever giving praise.

This quotation is used to demonstrate the belief of the verifiers that external realities ( $a^{\prime} y \bar{a} n$ khārijīyyah) are the result of the Divine names. As external reality emits from the names, it multiplies, only to eventually return to the names. This poem from the Gulshan-i Rāz clearly relates to this concept.

Also on the subject of the Divine attributes, Shams al-Dīn quotes another saying from the Gulshan-i Rāz:20

Dar ān majlis 'az̄̄z ān jumleh hādhir

Bad īn darwīsh har yek gusht nāzir ${ }^{21}$

All the nobles in that congregation

Turned their eyes upon this darvish ${ }^{22}$

Although in the Gulshan-i Rāz this poem is used to establish Shabistarī's reason for writing the book, Shams al-Dīn uses it in a more creative manner, to explain that God is present in all places the șüfi or darvish is.

In the first chapter of the Haqq al-yakin, Shams al-Dīn explains the various technical terms associated with the word wujūd (Being or existence). As he does so, he again quotes Shabistarī: ${ }^{23}$

Wujūd har yeki chūn būd vāhid

Biwaḥdaniyyat ḥaqq gusht shāhid ${ }^{24}$

Since the Being of all of them is One

They all bear witness to the unity of "the Truth" 25

In another, connected discussion also found in this chapter, Shams al-Dīn quotes Shabistarī again: 
Ahad dar mīm ahmad gusht zāhi

Dar īn dūr āmad awwal 'ayn akhirir

The One was made manifest in the mim of Ahmad

In this circuit the first emanation became the last. ${ }^{27}$

According to Lāhījīi, this quotation from the Gulshan-i Rāz refers to how the various entifications of existence are contained in the letter mim of Ahmad. ${ }^{28}$ This is also how Shams al-Dīn understands this quotation.

To demonstrate that man can know himself by seeing his attributes as reflections of God's attributes, Shams al-Dīn, in chapter four of the Haqq al-yakin, quotes: ${ }^{29}$

To 'ำ to nuskhaī naqsh ilāh $\overline{1}^{30}$

Bijo āz khuwish har chīzī keh khā' $\overline{1}^{31}$

Your self is a copy made in the image of God,

Seek in your self all that you desire to know. ${ }^{32}$

Shams al-Dīn's use of this quotation again mirrors the commentary by Lāhījī, which also argues that, in order for a person to know His Lord, all he needs to do is know his own self. This is because he is the Divine, in the sense that the Divine manifests Himself in the form of the Perfect Man..$^{33}$

In chapter five, Shams al-Dīn discusses the various Divine presences and their respective worlds, in the context of which another quotation is brought forward from the Gulshan-i Rāz: $:^{34}$

Muhạquīq rā keh bar waḥdat shuhūd ast

Nakhstīn nazarat bar nūr wujud ast ${ }^{35}$

He that knows "the Truth" 36 and to whom Unity is revealed

Sees at the first glance the light of very Being. ${ }^{37}$

This part of the Gulshan-i Rāz tries to answer the question, what is thought (fikr)? According to Lāhījīi, however, this section deals with a description of the perfect verifier and how the true reality of things becomes apparent for him through unveiling. ${ }^{38}$ Thus, in this instance we find that Lāhîjī's understanding of the text does not necessarily tie in with Shams al-Dīn.

In chapter seven of the Haqq al-yakin, Shams al-Dīn explains the perfection of God and again quotes a line from the Gulshan-i Rāz:

Ta'ayyun nukteh-i wahmīst dar 'ayn

Cheh șāfĩ gusht 'aynat ghayn shud 'ayn ${ }^{39}$

Phenomenal being is as the dot on 'ayn

When 'ayn is clear, ghayn becomes 'ayn $n^{40}$ 
Just as the difference between the letters 'ayn and ghayn lies in a single dot, so the differences between the different loci of manifestation and the Divine names that manifest within it are very small. ${ }^{41}$ This stresses man's closeness to God.

Chapter eight of the Haqq al-yakin concerns coming close to God. Here the text of Gulshan-i Rāz is quoted again:

Do khutwat bīsh nabūd rāh sālik

Agar cheh dārad ū chandīn mahālik

Yek az ha-ī huwiyyat dar guzashtan

Duwwom sahrā-1̄ hastî dar nawishtan ${ }^{42}$

The journey of the pilgrims (seekers) is two steps and no more

Although it is beset by divers perils

One step is passing out from that $\mathrm{H}$ of "He"

The second is passing over the field of existence..$^{43}$

Interestingly, Shams al-Dīn's use of this quotation is similar to that of Lāhījî̀'s commentary. Lāhījī talks about the two steps of the seeker - that is, annihilation and the state of subsisting. According to Lāhījī, these together constitute the stage of Haqq al-yaqin.$^{44}$ Shams al-Dīn, too, talks about annihilation and subsisting. $\mathrm{He}$, however, regards it as perfect strangeness if a person chooses death after reaching life which was the result of perfect knowledge of God.

In the last chapter of his work, Shams al-Dīn quotes from the Gulshan-i Rāz twice. The first concerns the degrees of the people of annihilation:

Marātib bāqī wa ahl marātib

Bazīr amr haqq wa Allah ghālib ${ }^{45}$

Dignities are permanent, but men of dignity

Are subject to the sway of the "Truth", Allah is over all. ${ }^{46}$

According to Lāhījīi , here Shabistarī is talking about the non-existence of freedom for the seeker, as God is always above and over his affairs. ${ }^{47}$ Shams al-Dīn, however, is explaining the connectivity between the immutable fixed entities and the various creations or external entities. Although this divergence is not explained, it does indicate to us that Shams al-Dīn was not a passive follower of the commentary.

In another place in the same chapter we find another quotation: ${ }^{48}$

Yekī beyn wa yekī Gū-ī wa yekī dān

Badīn khatm āmad aṣl wa far' īmān ${ }^{49}$

See but One, say One, know but One,

In this are summed up the roots and branches of faith ${ }^{50}$ 
For Lāhījīi, these verses refer to those seekers of truth who are at the level of witnesses. ${ }^{51}$ Shams al-Dīn, on the other hand, uses this quotation to explain that recollection is needed constantly at this level. This is an obvious divergence from Lāhījī, who instead elucidates and describes the station of achieving closeness with God and how this is achieved through His self-disclosure.

As these quotations show, Shams al-Dīn was greatly influenced by Shabistarī, from whom he borrowed many quotations to justify his own teachings. Moreover, there appears to be some similarity between Shams al-Dīn's own reading of the Gulshan-i Rāz and Lāhìjī's commentary upon the latter. This suggests Shams al-Dīn might have had a copy of the Mafātīh al-i'jāz fì sharh Gulshan-i Rāz for his reference. Indeed, it would not be too much to say that Shams al-Dīn was also influenced a great deal by Lāhìjī's work. However, as these quotations demonstrate, Shams al-Dīn was not a mere follower or passive teacher who borrowed without thinking. In fact, our discussion shows a deep thinking mind that utilised the teachings of past masters (particularly of the Ibn 'Arabī school) via an incorporation of their explanations into his own narrative of instruction. This paper has also demonstrated the ability of Malay scholars in Persian.

\section{Recommendations}

For the betterment of a clearer understanding of our past, the writer of these lines would like to recommend:

1. those of our local postgraduate students who intend to further their study in seventeenth-century Malay literature be given classes in Persian literature. As stated in this article, many seventeenth-century Malay scholars were influenced by Persian Sufi literature. Apart from Shabistarī, we could also highlight Fakhr al-Dīn al-Irāqī and Jalāl al-Dīn Rūmī. Proper exposure to Persian literature would equip our students with the knowledge necessary to study the writings of this era.

2. The teaching of Persian as an important Islamic language should also be given serious consideration, not just as an aid to understanding Malay heritage, but also in its own right.

3. A more holistic understanding of the development of Sufism and the transferal of Sufi-based literature should also be conveyed to future scholars. At the moment, the study of Sufism is limited to Arabic literature. Very few scholars master the other languages in which Sufi literature has been written and in which new forms of Sufism are expressed. ${ }^{52}$

4. The philological and doxological aspects of manuscript study should also be highlighted as an important part of all courses on traditional Malay literature. 
It is hoped that future Malay scholars will have the ability to speak, or at least read, literature in other Muslim languages, especially Persian. It is only by developing such abilities that the horizons of future Southeast Asian scholars will be broadened as much as they were in the past.

\section{Notes:}

* Mohamad Nasrin bin Mohamad Nasir is Research fellow at Institut Alam dan Tamaddun Melayu (ATMA) at Universiti Kebangsaan Malaysia. He may be reached at mnasrin@ukm.edu.my.

1. From this statement we can infer that Shams al-Dīn's parents were from Pasai and had then resettled in Aceh; if Shams al-Dīn were from Pasai, he would not say Aceh was his place of birth.

2. The Malay: "Maka bahawasanya hamba yang miskin yang berpegang kepada rahmat Tuhan seru 'ālam sekelian orang negeri Pasai asalnya dan nasabnya Shaykh Shams al-Din ibn Abi Abdillah al-Sumatra'i dan negeri Aceh jadinya dan kediamannya dan Imam Shafi'i imamnya dan mazhabnya," see Mohamad Nasrin bin Mohamad Nasir, A Critical Edition and Study of Haqq al-Yaqin fi Aqidat alMuhaqqiqin of Shams al-Din Sumatra'i, unpublished Ph.D dissertation, ISTAC, IIUM (2008), p. 129.

3. See my study above, pp. 11-15.

4. Nuru'd-din ar-Raniri, Bustanu 's-Salatin Bab II, Fasal 13, ed. T. Iskandar, (Kuala Lumpur: Dewan Bahasa dan Pustaka, 1966).

5. The Malay: "Syahdan pada masa itulah wafat Shaykh Syamsuddin ibn Abdillah al-Sumatrani pada malam Ithnin dua belas hari bulan Rejab pada Hijrah 1039 tahun. Adalah Shaykh itu alim pada segala ilmu dan ialah yang termasyhur pengetahuannya pada ilmu tasawuf dan beberapa kitab yang dita'lifkannya."

6. I would like to thank the staff at Pusat Manuskrip Melayu, Perpustakaan Negara Malaysia, for their help in accessing the manuscripts in question.

7. Haji Wan Mohd. Shaghir Abdullah, al-Ma'rīfah,Pelbagai Aspek Tasawwuf di Nusantara Jilid 1, Kuala Lumpur: Khazanah Fathaniyah dengan Kerjasama Yayasan Pembangunan Buku Negara (2004), pg. 63-8.

8. See Wan Mohd. Saghir Abdullah, 'Syeikh Syamsuddin as-Sumatra'i Ulama Sufi Pembesar Kerajaan Aceh', Penyebaran Islam \& Silsilah Ulama Sejagat Dunia Melayu, Kuala Lumpur: Khazanah Fathaniyyah (1999), pp. 39-47.

9. At the moment, I am preparing a paper analysing the various quotations taken from al-Jāmī by Malay Sufi texts. This article will be published by Brill in a volume dedicated to al-Jāmī and his influence in World literature. Forecasted date of publication is 2016 .

10. See Encyclopaedia Iranica, "Golshan-e Raz," and various articles connected to Maḥmūd Shabistarī in the Encyclopaedia of Islam. For studies on Shabistarī and description of his other writings see Lewisohn, L., Beyond Faith and Infidelity: Sufi Poetry and Teachings of Mahmud Shabistarī, Curzon Press, 1995 and Dr Abdul Husayn Zarinkub Justuju dar tasawwuf Iran, (Muassasah Intisharat Amir Kabir, 1349SH), 1349, 314-20. 
11. E.G. Browne, Literary History of Persia, vol. III, (India: Goodword Books, $2^{\text {nd }}$ edn., 2002), 472.

12. See also my paper on Hamzah Fansuri's usage of Persian quotations, 'Persian influences in the mysticism of Hamzah Fansuri', Measuring the Effects of Iranian mysticism on Southeast Asia, ed. Imtiyaz Yusuf, Bangkok: Cultural Centre, Embassy of the Islamic Republic of Iran, 2004, pp.74-99.

13. A. Hasjmy, 'Syekh Abdurrauf Syiah Kuala, Ulama Negarawan yang Bijaksana', Universitas Syiah Kuala Menjelang 20 Tahun, (Medan: Waspada, 1980), 370; this source is quoted in Azra's Jaringan Ulama, 230.

14. See R.A. Kern, "Pase" in Encyclopaedia of Islam $2^{\text {nd }}$ Edition, 279.

15. Azyumardi Azra, Edisi Revisi Jaringan Ulama Timur Tengah dan Kepulauan Nusantara Abad XVII \& XVIII, Akar Pembaruan Islam Indonesia, (Jakarta: Kencana, 2004), 230.

16. A recent Turkish study on the figure of Ibrahim al-Kurani included the possibility that one of Kurani's students, an Acehnese Shaykh called 'Abd al-Ra'üf Sinkil, had a Turkish father, see Saffet Bey, "Bir Osmanli Filosunun Sumatra Seferi," Tarikh-i Osmani Encumeni Mecmuasi, (Istanbul: 1327), 7-12. I would like to thank Hamid Algar, of the University California, Berkeley, for this rather interesting point.

17. See Encyclopaedia Iranica, “Golshan-e Raz,” Hamid Algar.

18. Ibid.

19. MS 2581 (F), pp. 77-8; pg. 17 of the Persian text and pg. 28 of the English translation as seen in E. H. Whinfield, Gulshan-i Rāz The Mystic Rose Garden of Sa'dud Dīn Maḥmūd Shabistarī, Islamic Foundation, Samanabad, Lahore, reprinted 1978. All subsequent Persian references and English translations are from this version of the text.

20. MS 2581 (F), pp. 81-2.

21. Whinfield, 4.

22. Whinfield, 4.

23. MS 2581(F) pg. 89; for the text in Malay see al-Ma'rīfah, Pelbagai Aspek Tasawwuf di Nusantara Jilid 1, Haji Wan Mohd. Shaghir Abdullah, Kuala Lumpur: Khazanah Fathaniyah dengan Kerjasama Yayasan Pembangunan Buku Negara (2004), pg. 77. Henceforth al-Ma'rïfah.

24. Whinfield, 42.

25. Whinfield, 70 .

26. Whinfield, 3. For this quotation, Shams al-Dīn does not produce the original Persian. I have therefore had to identify and reproduce the original passage from the Gulshan-i Rāz.

27. Whinfield, 2.

28. Lahiji, Mafātīh al-I'jāz. 44.

29. MS 2581(F), 99; pg. 92, al-Ma'rïfah.

30. There is a mistake in the text regarding this quotation from Shabishtarî's Gulshan-ī Rēz. This could have resulted from an editor's mistaken view that Shabishtarī wrote in Arabic. For the mistakes see ibid.

31. Whinfield, 26.

32. Whinfield, 45.

33. Lahiji, Mafātīḥ al-I'jāz, 374. 
34. MS 2581(F), 100; pg. 94, al-Ma'rīfah.

35. Whinfield, 6 .

36. In other words, the Verifiers.

37. Whinfield, 8 .

38. Lahiji, Mafātīh al-I'jāz, 78.

39. MS 2581(F), 115; pg. 115, al-Ma'rïfah and line 306, Whinfield, 19.

40. Whinfield, 31.

41. Lahiji, Mafātīh al-I'jāz.

42. MS 2581(F) pg. 116; pg. 116-7, al-Ma'rīfah and line 307-8, Whinfield, 19.

43. Whinfield, 32.

44. Lahiji, Mafātīh al-I'jāz, 247.

45. MS 2581(F) pg. 128; pg. 133, al-Ma'rīfah and line 535, Whinfield, 32.

46. Whinfield, 54.

47. Lahiji, Mafātīh al-I'jāz. 432.

48. MS 2581(F) pg. 136; pg. 144, al-Ma'rïfah.

49. Line 883, Whinfield, 51.

50. Whinfield, 84-5.

51. Lahiji, Mafātīh al-I'jāz. 643.

52. Of note here is Bukhari Lubis, a scholar who has written in Malay regarding Persian literature. See his many publications, published by DBP and Dewan Sastera, a Malay-language literary magazine.

\section{Bibliography}

Algar, Hamid, “GOLŠAN-E RĀZ” Encyclopaedia Iranica, Vol. XI, Fasc. 1, pp. 109-111.

Azra, Azyumardi. (2004). The Origins of Islamic Reformism in Southeast Asia: Networks of Malay-Indonesian \& Middle Eastern 'Ulama' in the Seventeenth and Eighteenth Centuries, University of Hawaii Press.

Azra, Azyumardi, Edisi Revisi Jaringan Ulama Timur Tengah dan Kepulauan Nusantara Abad XVII \& XVIII, Akar Pembaruan Islam Indonesia, (Jakarta: Kencana, Feb. 2004).

Browne, E.G. Literary History of Persia, vol. III, (India: Goodword Books, $2^{\text {nd }}$ edn.,2002).

Kern, R.A. "Pase" in Encyclopaedia of Islam 2 ${ }^{\text {nd }}$ Edition.

Lāhījī. Muḥammad ibn Yahyya (1377 Solar). Sharh Gulshan-I Rāz (Mafātīḥ alI’jāz). Tehran: Nashr Ilmi.

Lewisohn, L., Beyond Faith and Infidelity: Sufi Poetry and Teachings of Mahmud Shabistarī, Curzon Press, 1995.

Mohamad Nasrin Mohamad Nasir (2004). 'Persian influences in the mysticism of 
Hamzah Fansuri', Measuring the Effects of Iranian mysticism on Southeast Asia, ed. Imtiyaz Yusuf, Bangkok: Cultural Centre, Embassy of the Islamic Republic of Iran, 2004, pp.74-99.

Mohamad Nasrin Mohamad Nasir (2008). 'Persian quotation in the Haqq alYaqīn fì Aqìdat al-Muhaqqiqīn of Shams al-Dīn Sumatra'ì (d.1630)' al-Shajarah, vol. 11 no. 2, pp. 271-93.

Mohamad Nasrin bin Mohamad Nasir (2008). A Critical Edition and Study of Haqq al-Yaqīn fì Aqìdat al-Muhaqqiqīn of Shams al-Dīn Sumatra '̄, unpublished $\mathrm{PhD}$ dissertation, ISTAC, IIUM.

Nuru'd-din ar-Raniri, Bustanu's-Salatin Bab II, Fasal 13, edited by Dr T. Iskandar, (Kuala Lumpur: Dewan Bahasa dan Pustaka, 1966).

Shaykh Shams al-Dīn al-Sumatrā'̄̄, "Transliterasi Haqqul Yaqin”, in al-Ma'rifah, Pelbagai Aspek Tasawwuf di Nusantara Jilid 1, Haji Wan Mohd. Shaghir Abdullah, Kuala Lumpur: Khazanah Fathaniyah dengan Kerjasama Yayasan Pembangunan Buku Negara (2004), 68-150.

Seljuq, Affan, 'Relations between the Ottoman Empire and the Muslim Kingdoms in the Malay-Indonesian Archipelago', Die Welts des Islam, 301-10.

Wan Mohd. Saghir Abdullah, 'Syeikh Syamsuddin as-Sumatra'i Ulama Sufi Pembesar Kerajaan Aceh', Penyebaran Islam \& Silsilah Ulama Sejagat Dunia Melayu, Kuala Lumpur: Khazanah Fathaniyyah (1999), pp. 39-47.

Whinfield, E.H. Gulshan I Rāz The Mystic Rose Garden of Sa'dud Dìn Mahmūd Shabistarī, Islamic Foundation, Samanabad, Lahore, reprinted 1978.

Zarinkub, Abdul Husayn Justuju dar tasawwuf Iran, (Muassasah Intisharat Amir Kabir, 1349SH), 1349, 314-20. 